\title{
Inflammatory processes enhance cAMP-mediated uterus relaxation in the pregnant rat: the role of $T N F-\alpha$
}

\author{
Anna Klukovits • Árpád Márki • Eszter Páldy • \\ Sándor Benyhe • Márta Gálik • George Falkay • \\ Róbert Gáspár
}

Received: 29 July 2008 /Accepted: 15 November 2008 /Published online: 3 December 2008

(C) Springer-Verlag 2008

\begin{abstract}
The objective of this study was to assess the in vitro uterus relaxing potency of $\beta_{2}$-adrenergic receptor $\left(\beta_{2^{-}}\right.$ AR) agonists in pregnant rats after in utero administration of the bacterial lipopolysaccharide, Escherichia coli endotoxin (LPS). The LPS $(100 \mu \mathrm{g} / \mathrm{kg})$ was injected into the uterine lumen on day 16 of pregnancy. The effects of $\beta_{2}$-AR agonist terbutaline was tested in vitro, in isolated uterine rings precontracted by electric field stimulation. Uterine $\beta_{2}-\mathrm{AR}$ densities were detected by radioligand binding assay, the activated G-protein levels were investigated by a radiolabelled GTP binding assay. Uterine cAMP accumulation and the serum tumor necrosis factor- $\alpha$ (TNF- $\alpha$ ) levels were measured by enzyme immunoassay. The endotoxin-evoked preterm delivery occurred on day 21 . Higher $\mathrm{pD}_{2}$ values of terbutaline $(p<0.001)$ were detected in endotoxin-treated rats: $9.14 \pm 0.36$ vs. $7.71 \pm 0.12$ compared with sham-operated rats. The densities or the equilibrium dissociation constants of $\beta_{2}$-ARs were not different $(p>0.05)$ in LPS-treated vs. control animals. Serum TNF- $\alpha$ level rose threefold after LPS treatment, but this rise was abolished by thalidomide. In LPS + thalidomide-treated rats, the effect of terbutaline became similar to that in sham-operated controls. By the measurement of myometrial cAMP levels, we documented that the
\end{abstract}

A. Klukovits $(\bowtie) \cdot$ Á. Márki • M. Gálik · G. Falkay · R. Gáspár Department of Pharmacodynamics and Biopharmacy, University of Szeged,

H-6720 Szeged, Eötvös u. 6.,

Szeged, Hungary

e-mail: klukovits.anna@pharm.u-szeged.hu

E. Páldy $\cdot \mathrm{S}$. Benyhe

Institute of Biochemistry, Biological Research Center

of the Hungarian Academy of Sciences,

H-6726 Szeged, Temesvári krt. 62,

Szeged, Hungary concentration-response curve of terbutaline on cAMP accumulation was shifted to the left in the LPS-treated rats, with a significant rise in the $\mathrm{pD}_{2}$. We concluded that in the case of uterine inflammation, the in vitro uterus-relaxing potency of $\beta_{2}$-agonists enhances, which is possibly mediated by TNF- $\alpha$ and uterine cAMP levels and that may serve as a rationale for the use of $\beta_{2}$-AR agonists in the attenuation of preterm uterine contractions on an inflammatory basis.

Keywords Preterm birth · Inflammation .

Lipopolysaccharide $\cdot \beta_{2}$-receptor agonists $\cdot$ cAMP $\cdot$ TNF- $\alpha$

\section{Introduction}

Despite the broadly applied practice of aggressive tocolytic therapy for women with preterm uterine contractions, the incidence of preterm birth is stagnant or even increasing. Although a wide variety of tocolytic agents are used clinically, evidence regarding their efficacy is limited (Berkman et al. 2003; Smith 2003). The strongest evidence, in support of $\beta_{2}$-adrenergic receptor $\left(\beta_{2}-\mathrm{AR}\right)$ agonists, suggest a reduction in delivery within $24-48 \mathrm{~h}$, but rarely further delay in delivery and no evident reductions in infant morbidities. The lack of efficacy of tocolytic therapy may be due, in part, to the wide range of factors that cause preterm contractions (Garfield et al. 1998; Goldenberg et al. 2000; Challis et al. 2000, 2002; Wray et al. 2001) and because tocolytic therapy does not actually treat any underlying precipitating factors.

Intrauterine infection is present in approximately $25 \%$ of all cases (Romero et al. 1988), and the earlier the gestational age at delivery, the higher the frequency of intra-amniotic infection by Ureaplasma urealyticum, Mycoplasma hominis, Gardnerella vaginalis, certain peptos- 
trepococci, and Bacteroides species (Yoon et al. 1999; Peltier 2003). Interestingly, Watts et al. (1992) demonstrated that positive amniotic fluid cultures were present in $19 \%$ of women with intact membranes with no clinical evidence of intrauterine infection. It is well-known that inflammatory processes trigger a wide range of uterus-contracting factors: the influx of inflammatory cells into the uterus and elevated levels of pro-inflammatory cytokines [tumor necrosis factor- $\alpha$ (TNF- $\alpha)$, interleukin- $1 \beta,-6,-8]$, and prostaglandins were observed in human amnion during parturition (Lindström and Bennett 2005). The question is, whether these processes promote uterus-relaxing mechanisms as well.

For this reason, in this study, we aimed to investigate whether inflammatory processes affect the pharmacological potency of $\beta_{2}$-AR agonists. We set out to test the uterus-relaxing potencies of $\beta_{2}$-AR agonist terbutaline in pregnant rats previously challenged with the intrauterine administration of bacterial lipopolysaccharide (LPS), a byproduct mimicking an infection by Gram-negative bacteria (Elovitz and Mrinalini 2004). Systemic inflammation was followed-up by measurement of serum TNF- $\alpha$ levels. The agonist-induced $\beta_{2}$-AR activation was characterized by the measurements of uterine $\mathrm{G}_{\mathrm{s}}$-protein activation and cAMP accumulation.

\section{Materials and methods}

\section{Animals}

Animal investigations were carried out with the approval of the Institutional Review Board (permission number I74-8/2002 issued by the Ethical Committee for Animal Research at the University of Szeged).

Sexually mature female Sprague-Dawley rats (body mass $140-160 \mathrm{~g}, 50-60$ days old) were mated in the early morning hours. Copulation was confirmed by the presence of a copulation plug or spermatozoa in the vagina. The day of conception was considered to be the first day of pregnancy. The animals were housed in temperature- (20$23^{\circ} \mathrm{C}$ ), and humidity- (40-60\%), and light- (12 h of light, $12 \mathrm{~h}$ of dark) regulated rooms with water and food intake ad libitum.

In vivo treatments

Animals were divided into five groups ( $n=6-8$ in each): (1) nontreated controls; (2) LPS-treated; (3) sham-operated; (4) LPS + thalidomide-treated; and (5) thalidomide-treated.

Nontreated controls (1) were intact, 21-day pregnant rats. The administration of LPS was done on day 16 of pregnancy (2). Rats were anesthetized with ketaminexylazin $(45-5 \mathrm{mg} / \mathrm{kg}$ i.p.), then a midline abdominal incision was made, and the uterine horns were exposed. LPS $(100 \mu \mathrm{g} / \mathrm{kg}$ per horn in physiological saline) was carefully injected directly into the uterine lumen, into the gap between the amniotic membranes (Elovitz and Mrinalini 2004). The incisions in the abdomen were closed by separate surgical sutures, and the animals were kept under heating light until awakening from narcosis. The sham-operated rats (3) were injected with physiological saline into their uterine lumen on day 16 of pregnancy. To a group of animals (4), thalidomide $(45 \mathrm{mg} / \mathrm{kg}$; dissolved in $30 \%$ dimethyl-sulfoxide in physiological saline) was given in a single i.p. injection, $30 \mathrm{~min}$ before the LPS treatment to inhibit tumor necrosis factor- $\alpha$ (TNF- $\alpha$ ) production (Giamarellos-Bourboulis et al. 2003). Another group (5) was treated with i.p. thalidomide alone, on day 16 of pregnancy.

In vitro contractility studies

On day 21 of pregnancy, the rats were killed by $\mathrm{CO}_{2}$ inhalation at 12 A.M. (at preterm delivery), and the uteri were removed and prepared for the in vitro contractility assay as it was reported previously (Klukovits et al. 2004). Briefly, the isolated uterine horns were immediately placed in an organ bath (de Jongh solution; containing in mM: 137 $\mathrm{NaCl}, 3 \mathrm{KCl}, 1 \mathrm{CaCl}_{2}, 1 \mathrm{MgCl}_{2}, 12 \mathrm{NaHCO}_{3}, 4 \mathrm{Na}_{2} \mathrm{HPO}_{4}$, 6 glucose; $\mathrm{pH} 7.4$ ) perfused with $95 \%$ oxygen and $5 \%$ carbon dioxide; they were trimmed of fat, and the fetoplacental units were removed. Temperature was maintained at $37^{\circ} \mathrm{C}$. Four rings, $1 \mathrm{~cm}$ long, were sliced from the middle part of each horn including implantation sites and tested in parallel; they were mounted vertically between two platinum electrodes in the above-mentioned organ bath under the same conditions. After mounting, the initial tension was set at $1.5 \mathrm{~g}$, and the rings were equilibrated for $90 \mathrm{~min}$. Then, rhythmic contractions were elicited by electric field stimulation, performed by a digital, programmable stimulator (ST-02, Experimetria, Budapest, Hungary). The square pulse duration was set at $150 \mathrm{~ms}$, periodic time at $24 \mathrm{~s}$, and the supramaximal voltage at $40 \mathrm{~V}$ (Gaspar et al. 2001). After stimulation, terbutaline was added in noncumulative manner. Between two concentrations of the drug, the stimulation was suspended, tissues were washed extensively and allowed to recover. The tension of the myometrial rings was measured with a strain gauge transducer (SG-02, Experimetria, Budapest, Hungary) then recorded and analyzed by SPEL Advanced ISOSYS Data Acquisition System (Experimetria Ltd, Budapest, Hungary). The contraction inhibiting effects of terbutaline was expressed as the percentage of the precontraction before each concentration, both characterized by the area under the curve of 4min periods. The relaxing potency of terbutaline in the different groups of animals was compared on the basis of the $\mathrm{pD}_{2}$ values (negative logarithm of the effective 
concentration $\left.50 ;-\operatorname{logE} \mathrm{C}_{50}\right)$. The $\mathrm{pD}_{2}$ values were calculated for each concentration-response curve individually.

\section{Radioligand binding experiments}

Radioligand binding experiments were carried out on 21day pregnant rat uterus membrane preparations. The uterine tissues were cut and homogenized in buffer $(0.01 \mathrm{M}$ Tris$\mathrm{HCl}, 0.25 \mathrm{M}$ sucrose, $\mathrm{pH}$ 8.0) with an Ultra-Turrax T25 homogenizer (Janke\&Kunkel, IKA-Labortechnik Gmbh, Straufen Germany), and centrifuged $(20,000 \times g, 10 \mathrm{~min}$, $4^{\circ} \mathrm{C}$ ). The supernatants were stored at $4^{\circ} \mathrm{C}$, and the pellets were resuspended and recentrifuged. After mixing, the supernatants were centrifuged $\left(50,000 \times g, 60 \mathrm{~min} 4^{\circ} \mathrm{C}\right)$. The pellets were resuspended and stored at $-70^{\circ} \mathrm{C}$.

The reaction mixture contained $100 \mu \mathrm{l}$ membrane preparation $\left(\sim 0.5 \mathrm{mg} / \mathrm{ml}\right.$ protein), $100 \mu \mathrm{l}$ tritiated $\beta_{2}$-AR selective ligand $\left(\left[{ }^{3} \mathrm{H}\right] \mathrm{ICI} 118\right.$ 551; Bilski et al. 1983) with a specific activity of $18.8 \mathrm{Ci} / \mathrm{mM}$, and $100 \mu \mathrm{l}$ unlabeled ligand (isoproterenol) for nonspecific binding or $100 \mu \mathrm{l}$ incubation buffer (consisting of $0.05 \mathrm{M}$ Tris- $\mathrm{HCl}, 0.01 \mathrm{M} \mathrm{MgCl}_{2}$ and $2.5 \%$ ethanol, $\mathrm{pH}$ 7.42) for total binding. Protein was determined by the method of Bradford (1976). Incubation was started by addition of the membrane suspension and continued in a shaking water bath until a steady state was achieved $\left(30^{\circ} \mathrm{C}, 30 \mathrm{~min}\right)$. At the end of the incubation, the bound radioligand was separated from the residual-free radioligand by rapid filtration on a Brandell cell harvester (SEMAT, UK) through Whatman GF/C filters (SEMAT Technical, St. Albans UK) and washed with $3 \times 10 \mathrm{ml}$ icecold buffer (Tris-HCl, $\mathrm{pH}$ 7.42). The bound radioactivity was determined in a HighSafe scintillation cocktail in a Wallac 1409 liquid scintillation counter (Wallac, Turku, Finland).

Saturation analysis of $\beta_{2}$-ARs was performed with $\left[{ }^{3} \mathrm{H}\right]$ ICI118,551 $(0.5-10 \mathrm{nM})$ in the presence or absence of $1 \mu \mathrm{M}$ unlabeled isoproterenol. Specific binding was determined by subtracting the nonspecific binding from the total binding values. All assays were carried out at least three times in duplicate, and values are given as means \pm SEM. Saturation experiments were individually analyzed, the maximal numbers of binding sites $\left(B_{\max }\right)$ and the equilibrium dissociation constants $\left(K_{\mathrm{d}}\right)$ were calculated by Scatchard transformation of saturation curves.

\section{$\left[{ }^{35} \mathrm{~S}\right] \mathrm{GTP} \gamma \mathrm{S}$ binding assay}

The uterine tissue samples obtained from 21-day pregnant rats were homogenized, as it was reported previously (Gaspar et al. 2005) and were diluted in $50 \mathrm{mM}$ Tris- $\mathrm{HCl}$ buffer ( $\mathrm{pH}$ 7.4) to get appropriate protein content for the assays ( $\sim 10 \mu \mathrm{g}$ of protein/sample). The membrane fractions were incubated at $30^{\circ} \mathrm{C}$ for $60 \mathrm{~min}$ in Tris-EGTA buffer (pH 7.4) composed of $50 \mathrm{mM}$ Tris-HCl, $1 \mathrm{mM}$ EGTA,
$3 \mathrm{mM} \mathrm{MgCl} 2,100 \mathrm{mM} \mathrm{NaCl}$, containing $20 \mathrm{MBq} / 0.05 \mathrm{ml}$ $\left[{ }^{35} \mathrm{~S}\right] \mathrm{GTP} \gamma \mathrm{S}(0.05 \mathrm{nM})$, and increasing concentrations of terbutaline in the presence of excess GDP $(30 \mu \mathrm{M})$ in a final volume of $1 \mathrm{ml}$, according to Sim et al. (1995) and Traynor and Nahorski (1995), with slight modifications. Total binding $(T)$ was measured in the absence of test compound; nonspecific binding (NS) was determined in the presence of $10 \mu \mathrm{M}$ unlabeled GTP $\gamma \mathrm{S}$ and subtracted from total binding. The difference $(T-\mathrm{NS})$ represents basal activity. Bound and free $\left[{ }^{35} \mathrm{~S}\right] \mathrm{GTP} \gamma \mathrm{S}$ were separated by vacuum filtration through Whatman GF/B filters (Whatman, Dassel, Germany) with Brandel M24R Cell harvester. Filters were washed three times with $5 \mathrm{ml}$ ice-cold buffer $(\mathrm{pH}$ 7.4), and the radioactivity of the dried filters was detected in UltimaGold ${ }^{\mathrm{TM}} \mathrm{F}$ scintillation cocktail (Packard) with Packard Tricarb 2300TR liquid scintillation counter. Stimulation is given as percent of the specific $\left[{ }^{35} \mathrm{~S}\right] \mathrm{GTP} \gamma \mathrm{S}$ binding observed in the absence of receptor ligands (basal activity). $\left[{ }^{35} \mathrm{~S}\right] \mathrm{GTP} \gamma \mathrm{S}$ binding experiments were performed in triplicates and repeated at least three times. Data were analyzed by sigmoid dose-response curve fit option, $\mathrm{pD}_{2}$ values, and $E_{\max }$ values were also determined.

\section{Measurement of uterine cAMP accumulation}

Uterine tissue samples were incubated in de Jongh solution (containing in mM: $137 \mathrm{NaCl}, 3 \mathrm{KCl}, 1 \mathrm{CaCl}_{2}, 1 \mathrm{MgCl}_{2}, 12$ $\mathrm{NaHCO}_{3}, 4 \mathrm{Na}_{2} \mathrm{HPO}_{4}, 6$ glucose; $\mathrm{pH} 7.4$ ) at $37^{\circ} \mathrm{C}$, perfused with the mixture of $95 \%$ oxygen and $5 \% \mathrm{CO}_{2}$. Cyclic AMP generation was stimulated with terbutaline for $10 \mathrm{~min}$, in the presence of the nonspecific phosphodiesterase inhibitor 3-isobutyl-1-methylxanthine $(1 \mathrm{mM})$, then the samples were immediately frozen in liquid nitrogen and stored there until the extraction of cAMP (Sartori et al. 2002; Gaspar et al. 2007). Then, frozen tissue samples were ground, weighed, homogenized in ten volumes of ice-cold $5 \%$ trichloroacetic acid and centrifuged at $600 \times \mathrm{g}$ for $10 \mathrm{~min}$. The supernatants were extracted with three volumes of water-saturated diethyl ether. After drying, the extracts were stored at $-70^{\circ} \mathrm{C}$ until the cAMP assay. Uterine cAMP accumulation was measured with a commercial competitive cAMP Enzyme Immunoassay (EIA) Kit (Sigma-Aldrich Ltd, Budapest, Hungary), and tissue cAMP levels were expressed in $\mathrm{pmol} / \mathrm{mg}$ tissue.

\section{Measurement of serum TNF- $\alpha$ level}

On selected days of pregnancy $(16,17,21)$, rats were anesthetized with isoflurane, and blood samples were taken by cardiac puncture. After centrifugation at $1,800 \times \mathrm{g}$ for $10 \mathrm{~min}$, the sera were collected and stored at $-70^{\circ} \mathrm{C}$ until the TNF- $\alpha$ assay. Serum TNF- $\alpha$ concentrations were determined by a commercial direct enzyme linked immu- 
noassay (ELISA) kit and were expressed as $\mathrm{pg} / \mathrm{ml}$. The TNF- $\alpha$ ELISA Kit was manufactured by Biocompare and was purchased from Izinta, (Budapest, Hungary).

\section{Statistical analyses}

All experiments were carried out on at least six animals, and each value is given as a mean \pm SEM. All the curve fittings (sigmoidal dose-response curves) and statistical analyses were performed with the Prism 4.01 computer software (Graph Pad Software, San Diego, CA, USA). Group comparisons were made by one-way ANOVA tests with Newman-Keuls posttest $\left(\mathrm{pD}_{2}\right.$ value, maximal relaxing effect in the contractility assays, cAMP accumulation, and serum TNF- $\alpha$ ), and paired comparisons were made by Student's $t$ test $\left(B_{\max }, K_{\mathrm{d}}\right.$ in the receptor assays, $\mathrm{pD}_{2}$, and maximal percent change in the $\left[{ }^{35} \mathrm{~S}\right] \mathrm{GTP} \gamma \mathrm{S}$ binding assays).

\section{Drugs}

Terbutaline hemisulfate, isoproterenol hydrochloride, ketamine hydrochloride, xylazine hydrochloride, Escherichia coli 055:B5 lipopolysaccharide, thalidomide, and 3-isobutyl-1-methylxanthine were purchased from SigmaAldrich, Budapest, Hungary. $\left.{ }^{3} \mathrm{H}\right] \mathrm{ICI} 118,551$ (erythro-DL1(-methylindan-4-yloxy)-3-isopropylamino-butan-2-ol) and $\left[{ }^{35} \mathrm{~S}\right] \mathrm{GTP} \gamma \mathrm{S}$ were purchased from Tocris Cookson, Avonmouth, UK.

\section{Results}

Uterine activity was characterized by the AUC of electric field (EF) stimulated contractions. Representative online recordings of the in vitro motor activity of uterine ring preparations from sham-operated (a), LPS-treated (b), and LPS + thalidomide-treated (c) rats are presented in Fig. 1. Neither LPS- nor LPS + thalidomide treatment altered significantly the EF-stimulated rhythmic uterine contractions compared with the sham-operation $(p>0.05$ in both comparisons; regarding the $4 \mathrm{~min}$ AUCs of all experiments). In both the nontreated and the sham-operated control rats, terbutaline concentration dependently inhibited the rhythmic contractions of the isolated uterine rings (Fig. 2). Neither the $\mathrm{pD}_{2}$ nor the maximal contractioninhibiting effects of terbutaline was found to differ significantly in the sham-operated control group compared with the nontreated control animals $(p>0.05$; Table 1$)$. In LPS-treated rats, however, the relaxing effect of terbutaline was characterized by a significantly higher $\mathrm{pD}_{2}$ value compared with either the nontreated $(p<0.001)$ or the sham-operated control rats $(p<0.001)$, also shown by the shift of the concentration-response curve to the left. In LPS-treated rats, the maximal contraction-inhibiting effect of terbutaline was not changed significantly $(p>0.05)$.

To investigate the background of the enhanced potency of the tested $\beta_{2}$-adrenergic agonists, the uterine $\beta_{2}$-AR density was determined by radioligand binding technique. The Scatchard analysis indicated (Fig. 3) that neither the
Fig. 1 Representative online recordings of the in vitro motor activity of uterine ring preparations from (a) sham-operated, (b) LPS-treated, and (c) LPS + thalidomide-treated rats. Contractions were elicited by electric field stimulation (EFS; pulse width $150 \mathrm{~ms}$, periodic time $24 \mathrm{~s}$, voltage $40 \mathrm{~V}$ ) and the contraction-inhibiting effects of terbutaline was expressed as a percentage of the precontraction before each concentration, both characterized by the area under the curve of 4 min periods. $S$ with solid arrows the onset of stimulation, dashed arrows the addition of terbutaline, $E$ with dashed arrows end of stimulation, $W$ washing period a

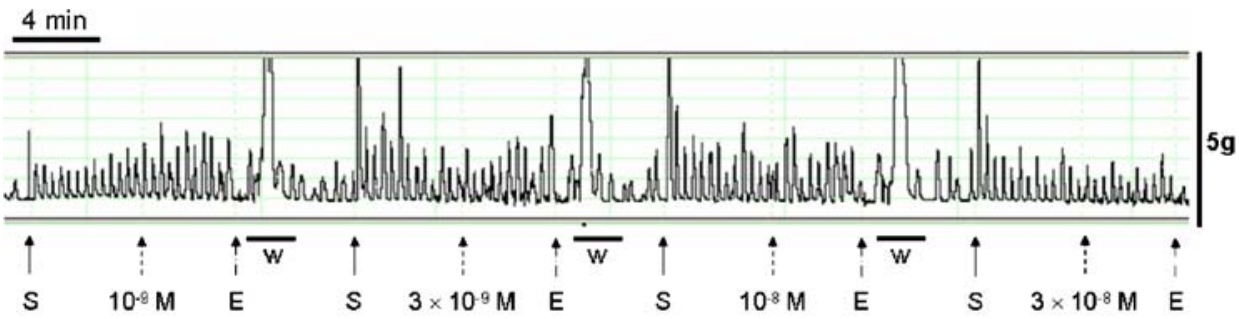

b

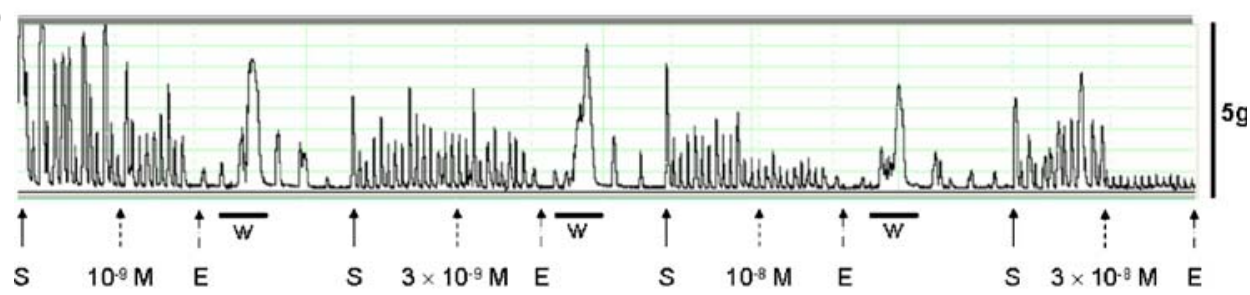

C

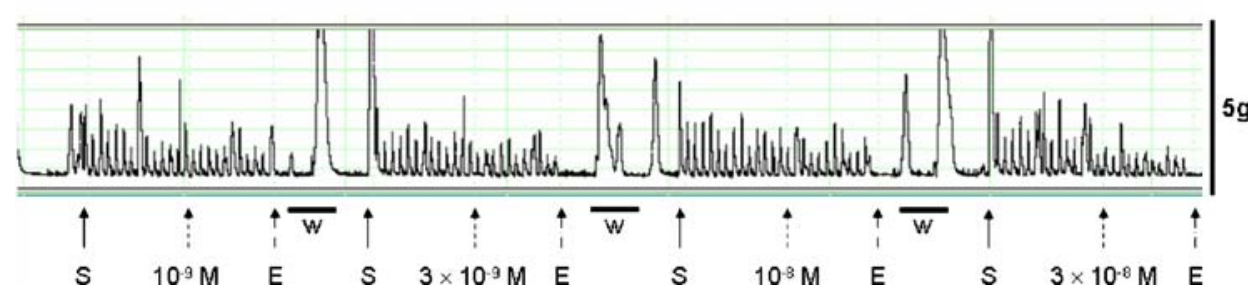




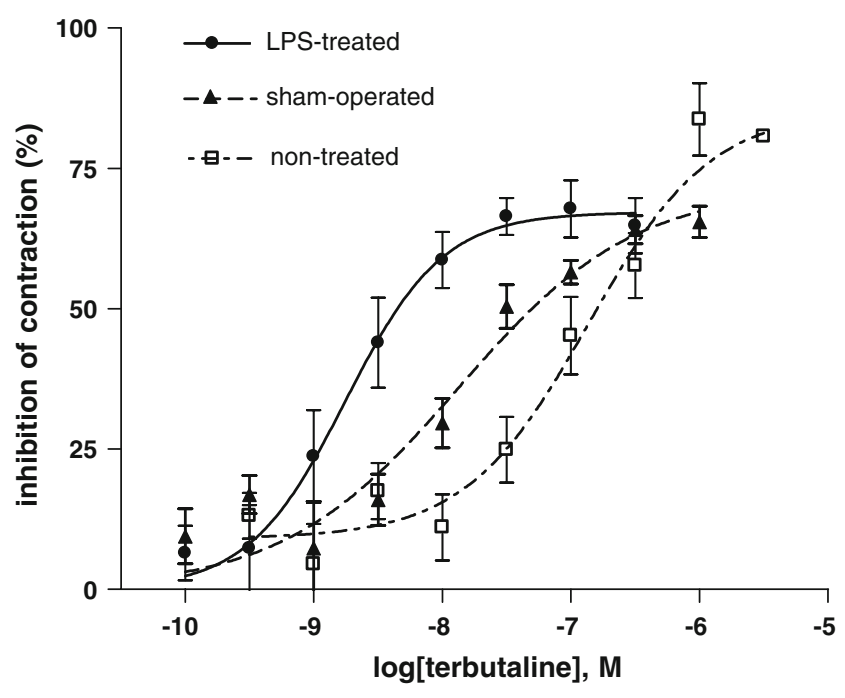

Fig. 2 Concentration-response curves of the action of terbutaline on isolated uterine rings of nontreated, sham-operated, and LPS-treated rats on day 21 of pregnancy. Intrauterine LPS treatment on day 16 of pregnancy caused a marked shift to the left of the concentrationresponse curve compared with the sham-operated controls, which reveals an enhanced potency of terbutaline. The responses to each concentration of terbutaline are expressed as the percentage inhibition of the rhythmic contractions evoked by electric field stimulation, where the activity of the uterine rings is characterized by the AUC. Values are given as mean $\pm \mathrm{SEM} ; n>6$ in all cases

$B_{\max }$ of $\beta_{2}$-ARs (in fmol/mg protein: $216.65 \pm 49.14$ in the nontreated and $263.40 \pm 15.27$ in the LPS-treated group) nor the $K_{\mathrm{d}}$ values (in nM: $1.41 \pm 0.07$ in the nontreated and $1.51 \pm$ 0.45 in the LPS-treated group) were significantly different $(p>0.05)$, which points to the similarity of both the maximum number of binding sites and the binding affinities. No significant change was found in the terbutaline-stimulated $\left[{ }^{35} \mathrm{~S}\right] \mathrm{GTP} \gamma \mathrm{S}$ binding through the $\beta_{2}$-ARs in LPS-treated and nontreated rats (Fig. 4). Neither the $\mathrm{pD}_{2}$ values $(8.21 \pm 0.41$ in the nontreated and $8.04 \pm 0.35$ in the LPS-treated group) nor the maximal stimulation values (in percent: $110.8 \pm 2.5$ in the nontreated and $107.9 \pm 0.5$ in the LPS-treated group) of

Table 1 The summary of the $\mathrm{pD}_{2}$ values and maximal contractioninhibiting effects of terbutaline on the isolated uteri of control and differentially treated 21-day pregnant rats ( $n>6$ in each group)

\begin{tabular}{llc}
\hline Animal group & pD2 value & $\begin{array}{c}\text { Maximal contraction- } \\
\text { inhibiting effect (\%) }\end{array}$ \\
\hline Nontreated & $7.37 \pm 0.11$ & $85.21 \pm 7.54$ \\
Sham-operated & $7.71 \pm 0.12$ & $80.47 \pm 5.86$ \\
LPS-treated & $9.14 \pm 0.36^{* * *}$ & $67.19 \pm 4.28$ \\
LPS + THAL-treated & $7.38 \pm 0.14$ & $82.26 \pm 6.43$ \\
THAL-treated & $7.53 \pm 0.29$ & $73.36 \pm 4.52$ \\
\hline
\end{tabular}

LPS lipopolysaccharide, THAL thalidomide

$* * * p<0.001$ refers to the level of significant difference from all other tested groups.

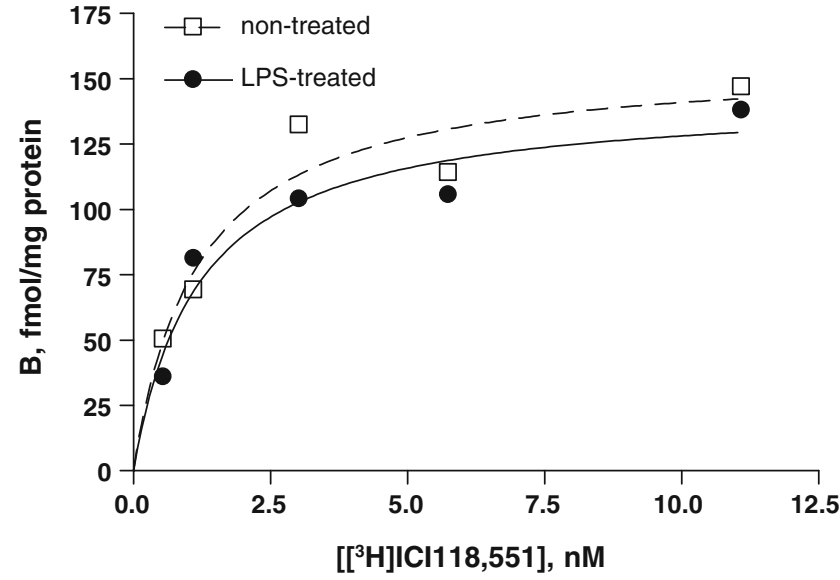

Fig. 3 Representative saturation-binding curves of $\beta_{2}$-adrenergic receptors $\left(\beta_{2}\right.$-ARs) in the uteri of LPS-treated and nontreated rats, on day 21 of pregnancy. Receptor bindings were determined with a radioligand-binding technique using rat uterine membrane preparations. Saturation analysis of $\beta_{2}$-ARs was performed with $\left[{ }^{3} \mathrm{H}\right]$ ICI118,551 $(0.5-10 \mathrm{nM})$ in the presence or absence of $1 \mu \mathrm{M}$ unlabeled isoproterenol. All assays were carried out at least three times in duplicate, and values are given as means \pm SEM. Similarly fitted curves reveal no alterations $(p>0.05)$ in the maximum numbers $\left(B_{\max }\right)$ and the equilibrium dissociation constants $\left(K_{\mathrm{d}}\right)$ of the $\beta_{2}$-ARs in the uteri of LPS-treated compared with the nontreated control rats

terbutaline on $\left[{ }^{35} \mathrm{~S}\right] \mathrm{GTP} \gamma \mathrm{S}$ binding were statistically different $(p>0.05)$. In this assay, $\left[{ }^{35} \mathrm{~S}\right] \mathrm{GTP} \gamma \mathrm{S}$ replaces endogenous GTP and binds to the $\alpha$ subunit of G-protein, stabilizes it, and then the accumulation of labeled $\mathrm{G}_{\alpha}$ subunits can be measured by counting the amount of ${ }^{35} \mathrm{~S}$ incorporated.

Terbutaline also concentration dependently enhanced the uterine cAMP accumulation in the uteri of sham-operated and LPS-treated rats (Fig. 5). Similarly as in the contrac-

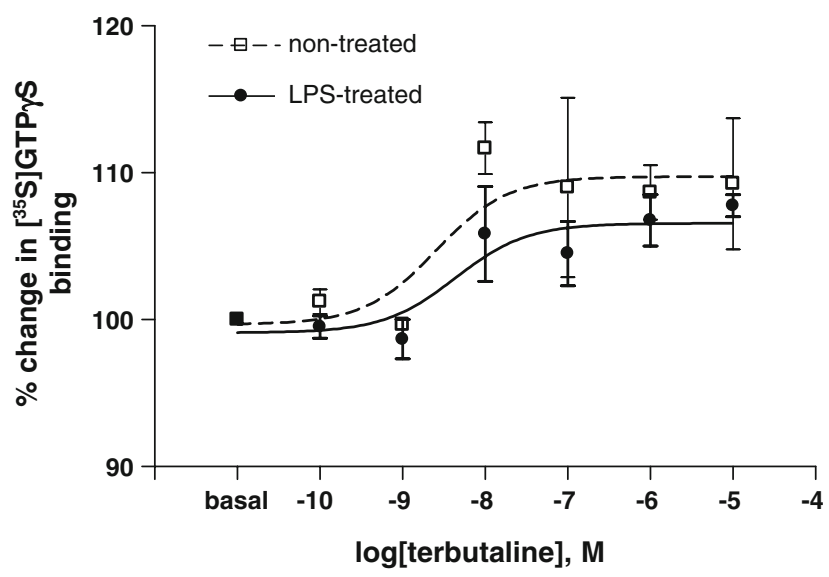

Fig. 4 Changes in $\left[{ }^{35} \mathrm{~S}\right] \mathrm{GTP} \gamma \mathrm{S}$ binding to uterine membranes in LPStreated and nontreated rats on day 21 of pregnancy by various concentrations of terbutaline. The basal value is that of $\left[{ }^{35} \mathrm{~S}\right] \mathrm{GTP} \gamma \mathrm{S}$ binding without terbutaline stimulation and was regarded as 100 . Points are means \pm SEM from three separate experiments carried out in triplicate. Neither the maximal values nor the $\mathrm{pD}_{2}$ values of terbutaline on $\left[{ }^{35} \mathrm{~S}\right] \mathrm{GTP} \gamma \mathrm{S}$ binding were statistically different $(p>0.05)$ 


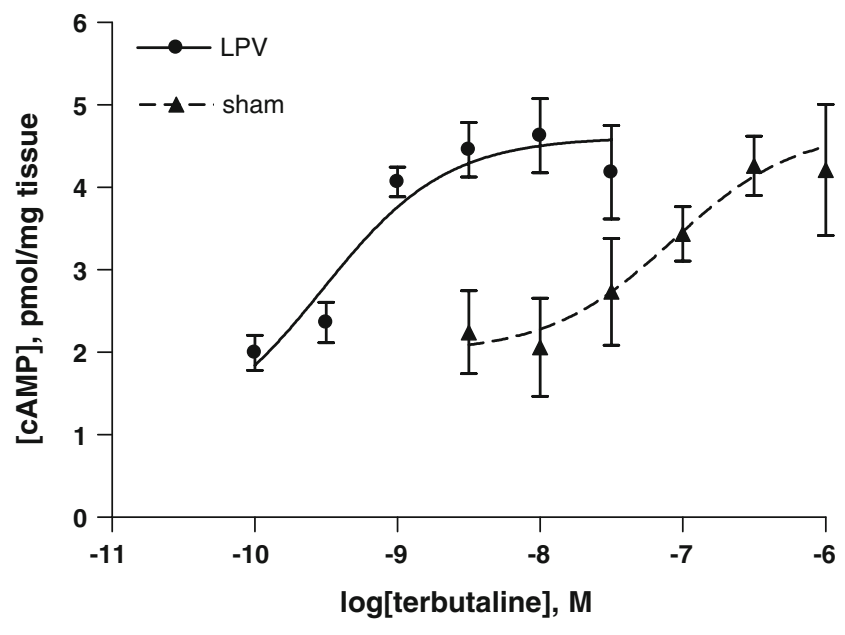

Fig. 5 Concentration-response curves of the action of terbutaline on uterine cAMP accumulation in LPS-treated and in sham-operated rats, on day 21 of pregnancy. The cAMP levels were determined by enzyme immunoassay. In LPS-treated rats, the curve is shifted to the left which indicates that terbutaline elicits a similar rise in myometrial cAMP levels at lower concentrations in LPS-treated rats compared with the sham-operated rats. Values are given as mean $\pm \mathrm{SEM} ; n=6$ in all groups

tility studies, the concentration-response curve of terbutaline on cAMP accumulation was shifted to the left in the LPS-treated rats, with a significant rise in the $\mathrm{pD}_{2}(6.74 \pm$ 0.26 in the sham-operated and $9.33 \pm 0.15$ in the LPStreated group, $p<0.05)$. It seems that the enhanced relaxing potency of terbutaline is directly related to its enhanced cAMP accumulating effect. Terbutaline induced the accu- mulation of cAMP at similar concentrations to those that evoked noteworthy relaxing effects on the uterine rings.

The ongoing inflammatory process was followed by the measurement of serum TNF- $\alpha$ levels. Since thalidomide is a known inhibitor of TNF- $\alpha$ production, we tested how a single dose of thalidomide given prior to the intrauterine LPS challenge affects blood TNF- $\alpha$ levels and whether it affects the LPS-induced changes in the uterus relaxing effects of terbutaline. The serum TNF- $\alpha$ level (Fig. 6) was $8.18 \pm 3.00 \mathrm{pg} / \mathrm{ml}$ in intact rats, on day 16 of pregnancy. On day 17, sham-operation caused a slight but not significant $(p>0.05)$ rise of TNF- $\alpha$ level to $36.17 \pm 3.79 \mathrm{pg} / \mathrm{ml}$, whereas the intrauterine inoculation of LPS increased the serum level of TNF- $\alpha$ to $179.60 \pm 36.92 \mathrm{pg} / \mathrm{ml}$, which was significantly $(p<0.001)$ higher than in the sham operated rats. Co-administration of thalidomide with LPS abolished this rise of serum TNF- $\alpha$ concentration $(9.53 \pm 4.61 \mathrm{pg} / \mathrm{ml})$ compared with the LPS treatment; in this group, there was no statistical difference $(p>0.05)$ from the sham-operation. On day 21 , the serum TNF- $\alpha$ concentration was significantly $(p<0.05)$ higher in the LPS-treated rats $(122.20 \pm 24.92 \mathrm{pg} / \mathrm{ml})$ than in either the sham-operated rats $(33.71 \pm 9.71 \mathrm{pg} / \mathrm{ml})$ or in the LPS + thalidomidetreated rats $(46.40 \pm 7.97 \mathrm{pg} / \mathrm{ml})$.

We also found that the inhibition of TNF- $\alpha$ synthesis by thalidomide in the LPS-treated rats altered the uterusrelaxing effect of terbutaline (Fig. 7). Thalidomide alone had no effect on the concentration-response curve of terbutaline; no significant change was found in the $\mathrm{pD}_{2}$ $(p>0.05)$ or in the maximal inhibitory effect $(p>0.05)$ compared with the nontreated controls. In the LPS +

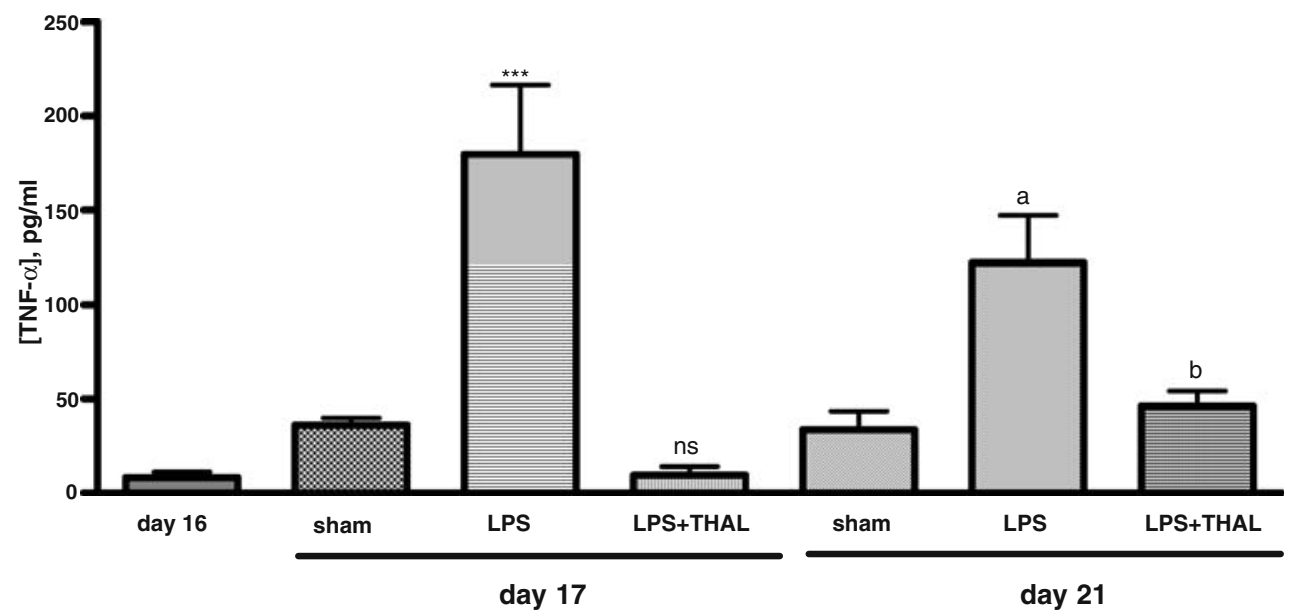

Fig. 6 Serum TNF- $\alpha$ levels in intact rats (on day 16 of pregnancy), and in sham-operated, LPS-treated and LPS + thalidomide-treated rats on days 17 and 21 of pregnancy. On day 17, $24 \mathrm{~h}$ after LPS inoculation, the serum TNF- $\alpha$ levels were significantly $(* * * p<0.001)$ increased in LPS-treated compared with the sham-operated rats. Thalidomide given $30 \mathrm{~min}$ prior to LPS prevented the rise in the serum TNF- $\alpha$ concentration which did not differ significantly from that in the sham-operated rats $(n s p>0.05)$. On day 21 , the serum TNF- $\alpha$ levels were still significantly higher $(a p<0.05)$ in the LPStreated compared with the sham-operated rats. In rats that received LPS+ thalidomide, the TNF- $\alpha$ concentration did not differ significantly from that in the sham-operated rats $(b p>0.05)$. Values are given as means $\pm \mathrm{SEM} ; n=6$ in all groups 


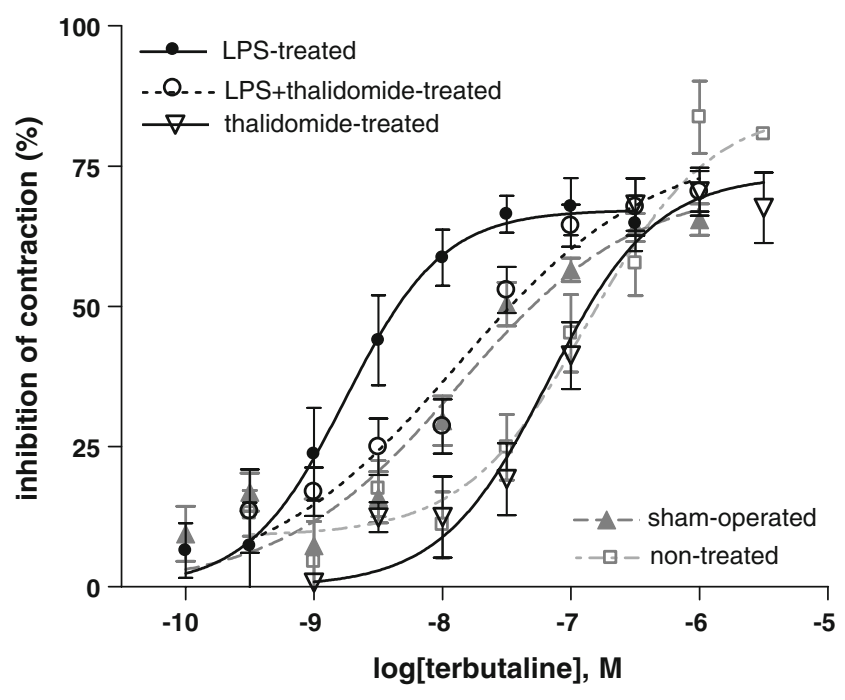

Fig. 7 Concentration-response curves of the action of terbutaline on isolated uterine rings of the LPS-treated, LPS + thalidomide-treated, and thalidomide-treated rats, and also those of the sham-operated and nontreated controls on day 21 of pregnancy, respectively. The administration of thalidomide alone did not change the effect of terbutaline compared with nontreated controls. Thalidomide given prior to the intrauterine LPS treatment in part prevented the LPSinduced shift of the concentration-response curve to the left compared with the sham-operated controls. The responses to each concentration of terbutaline are expressed as the percentage inhibition of the rhythmic contractions evoked by electric field stimulation, where the activity of the uterine rings is characterized by the AUC. Values are given as means \pm SEM; $n>6$ in all cases

thalidomide-treated rats, however, the $\mathrm{pD}_{2}$ of terbutaline was similar to that of the sham-operated controls $(p>0.05)$, but at the same time, significantly lower than in rats treated with LPS only $(p<0.001)$. Thus, the co-administration of thalidomide with LPS abolished the left shift of the concentration-response curve of terbutaline. The $\mathrm{pD}_{2}$ values and the maximal inhibitory effects of terbutaline in the thalidomide-treated groups are also listed in Table 1.

With regard to the uterine cAMP accumulation, the coadministration of thalidomide with LPS also reversed the LPS-induced change in the uterine cAMP accumulating effect of terbutaline (Fig. 8). Similarly as in the contractility studies, the concentration-response curve of terbutaline on cAMP accumulation was similar to that of sham-operated rats, without a significant rise in the $\mathrm{pD}_{2}$ values $(6.74 \pm 0.26$ in the sham-operated and $8.11 \pm 0.51$ in the LPS + thalidomide-treated group, $p>0.05$ ).

\section{Discussion}

Preterm delivery is one of the major determinants of infant mortality and morbidity. The $\beta_{2}$-AR agonists (ritodrine, terbutaline, hexoprenaline) have an important role in the management of preterm birth, although their therapeutic efficacy is constantly being questioned. Recent articles published in the Lancet or in the Cochrane Database of Systematic Reviews approve that $\beta_{2}$-AR agonists ritodrine and terbutaline can delay delivery by $48 \mathrm{~h}$ (Iams et al. 2008; Withworth and Quenby 2008). However, there are some concerns about their safety regarding unfavorable side effects such as tachycardia and the risk of pulmonary hypertension. Other treatment choices are the oxytocin antagonist atosiban, magnesium sulfate, or the $\mathrm{Ca}^{2+}$ channel blocker nifedipin. Up-to-date evidences that would support the use of magnesium sulfate as a tocolytic are poor, and there are concerns about the effectiveness and safety of atosiban and nifedipin as well (de Heus et al. 2008; Kam and Lamont 2008). Recent publications by a group of scientists would promote the use of phosphodiesterase 4 inhibitors, especially in the case of intrauterine inflammation, but clinical experiences are underway (Méhats et al. 2007).

In our present study, we tested whether the long-standing used $\beta_{2}$-AR agonists have therapeutical benefit if preterm uterine contractions were triggered by an inflammatory process. Inflammation is believed to be a contributing factor in many cases of preterm birth, and it often remains unidentified. Obviously, there are some serious situations (e.g., manifest chorioamnionitis) when preterm birth serves the health of both the mother and the infant, but in most cases, unfortunately, there are no such obvious reasons to be detected. The main rationale for the use of tocolytic drugs is to delay delivery until the mother is transferred to a specialist unit which can increase the survival of preterm

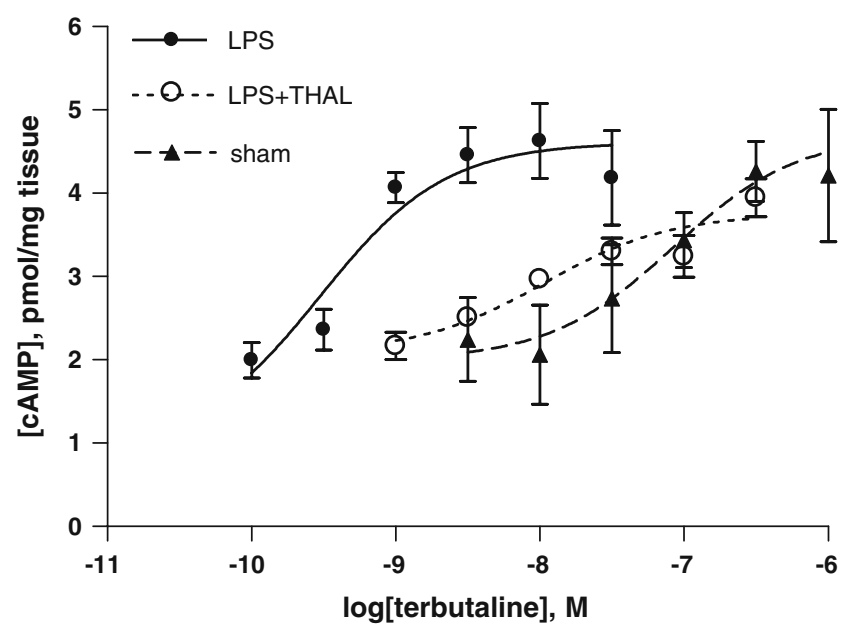

Fig. 8 Concentration-response curves of the action of terbutaline on uterine cAMP accumulation in LPS-treated, LPS + thalidomidetreated and sham-operated rats, on day 21 of pregnancy. The cAMP levels were determined by enzyme immunoassay. Thalidomide treatment prevented the LPS-induced left shift of the curve. Values are given as means \pm SEM; $n=6$ in all groups 
infants due to obstetric interventions (screening for asymptomatic bacteriuria, prophylactic antibiotic treatment for group B streptococcal infections, and antenatal corticosteroid treatment; Iams et al. 2008).

Our results revealed that terbutaline has an enhanced relaxing potency on the isolated uteri of the LPS-treated rats. The $\mathrm{pD}_{2}$ value of terbutaline was significantly higher in the case of inflammation, without meaningful changes in the maximal relaxing effect, suggesting a change in some receptor-mediated responses. Since the enhanced potency of a pharmacologically active substance may be related either to an increase in receptor number or to the enhancement in post-receptorial signaling pathways, we investigated the $\beta_{2}$-AR density, the $\beta_{2}$-AR-coupled Gprotein activation, and the agonist-stimulated cAMP accumulation in the late-pregnant rat uterus. We detected that neither the $\beta_{2}$-AR density nor the affinity of terbutaline to the $\beta_{2}$-receptors was different in LPS-treated versus nontreated rats. Furthermore, the activated G-protein-increasing effect of terbutaline was also not significantly different in LPS-treated versus nontreated rats. By this assay, we measured the functional consequences of receptor occupancy in one of the earliest receptor-mediated events (Harrison and Traynor 2003).

Although the uterine inflammatory processes did not affect the maximal G-protein activating property of terbutaline, it did change the local cAMP accumulation. By the measurement of myometrial cAMP levels, we documented that the concentration-response curve of terbutaline on cAMP accumulation was shifted to the left in the LPStreated rats, with a significant rise in the $\mathrm{pD}_{2}$. It explains why we could report an enhanced uterine relaxing effect of terbutaline in the uteri of LPS-treated rats. For example, $10^{-8} \mathrm{M}$ terbutaline elicited an approximately two times greater effect in LPS-treated than in sham rats regarding either the percentage of contraction inhibition or the uterine cAMP accumulation. It seems that the local cAMP levels well correlate with the in vitro effects of terbutaline.

Further, we looked for the possible reasons of the altered $\beta_{2}$-AR-mediated relaxation responses. Since previous investigations have reported an increased cAMP signaling in the presence of TNF- $\alpha$ in cultured human myometrial cells (Gogarten et al. 2003), we hypothesized that the generation of some inflammatory mediators leads to the enhanced synthesis of cAMP and the increased relaxing potency of $\beta_{2}$-AR agonists in the uterus. For this reason, serum TNF- $\alpha$ levels were measured before and after the inoculation of LPS, and rats were pretreated with thalidomide, a known inhibitor of TNF- $\alpha$ synthesis (Combe 2001; Kim et al. 2004), prior to the LPS treatment, and the uteri of this group were also tested in the contractility assays and for cAMP accumulation. We note here that the single dose of thalidomide given on day 16 was indicated merely for theoretical purposes, to study a possible link between TNF$\alpha$ and the myometrial cAMP generation.

Thalidomide administration abolished the LPS-evoked rise in serum TNF- $\alpha$ concentration at $24 \mathrm{~h}$, and its diminishing effect on TNF- $\alpha$ levels was still detectable at the time of preterm parturition. Moreover, thalidomide prevented in part the left-shift of the concentrationresponse curve of terbutaline in LPS-treated rats in the contractility as well as the cAMP accumulation assays. Thus, by the inhibition of TNF- $\alpha$ synthesis in the LPStreated animals, the potentiation of the relaxing effect or cAMP-accumulating effect of terbutaline is nearly abolished which promotes the role of TNF- $\alpha$ in altered signaling through $\beta_{2}$-ARs.

A possible explanation for the TNF- $\alpha$-related changes in uterine cAMP levels might be the adenylyl cyclase sensitization in the myometrial plasma membrane. Osawa et al. (2007) reported recently that, in human airway smooth muscle cells, chronic exposure to TNF- $\alpha$, by the transactivation of epidermal growth factor receptors, induces a raf-1 kinase-mediated phosphorylation and activation of the adenylyl cyclase enzyme, leading to a "cAMP overshoot." That kind of adenylyl cyclase sensitization, which does not affect receptor binding or $\mathrm{G}_{\mathrm{s}}$ protein activation, might be responsible for the altered cAMP-mediated relaxation processes in the rat myometrium as well.

Our finding that the inflammatory processes augment the cAMP-mediated relaxation in the rat uterus is novel, since previous studies reported opposite regulation of $\beta_{2}$-ARmediated responses by inflammatory processes. In the mouse airways, IL- $1 \beta$ and TNF- $\alpha$ induce desensitization (phosphorylation) of the $\beta_{2}$-ARs and decrease cAMP levels (Guo et al. 2005). In the pregnant rat uterus, however, we demonstrated that inflammatory mediators might be able to stimulate the synthesis of cAMP. We concluded that the LPS-induced elevation of the serum TNF- $\alpha$ level probably plays an important role in the altered responsiveness to $\beta_{2^{-}}$ AR activation. TNF- $\alpha$ is probably not the only cytokine involved in this regulatory process, but it has been proved to be a meaningful one.

Nevertheless, local cAMP levels in the myometrium cells are also regulated by the cyclic nucleotide phosphodiesterases (PDEs) which hydrolyze cAMP to inactive 5'AMP. Any change in PDE expression or activity may alter cAMP-mediated relaxation responses in the myometrium. We think, however, that measuring PDE activity or detecting the changes in the expressions of several known PDE isoforms in the rat myometrium would go far beyond the limits of this paper. At the same time, we wish to mention that, in a recent study, no change was observed in the PDE activity and PDE4B2 expression in the uterine tissues of LPS-challenged pregnant mice (Schmitz et al. 2007). Here, we intended to focus on the possible 
alterations of the $\beta_{2}$-adrenergic receptor-mediated uterus relaxation in the late-pregnant rat uterus in inflammatory conditions, as well as receptor binding, receptor-coupled Gprotein activation, and cAMP accumulation.

To summarize the above findings, our results reveal an altered responsiveness of the rat myometrium to $\beta_{2}$-AR agonists in consequence of intrauterine inflammation. Although the inflammation itself does not alter the $\beta_{2}$-AR density, it may lead to changes in the $\mathrm{G}_{\mathrm{s}}$-coupled adenylyl cyclase activity and enhanced myometrial cAMP accumulation. Although the enhanced relaxing potency of $\beta_{2^{-}}$ agonists is a consequence of a pathological condition, it may become beneficial with regard to tocolytic therapy. The enhanced potency of $\beta_{2}$-agonists may promote the administration of lower doses, which would be equally effective in relaxing the uterus, thereby avoiding the early onset of side effects and delaying the homologous desensitization of $\beta_{2}$-ARs that limits the long-term administration of $\beta_{2}$-agonists. Besides, there are evidences that the $\beta_{2}$-AR agonists possess anti-inflammatory properties which is cAMP- and protein kinase A-dependent (Farmer and Pugin 2000; Maris et al. 2005). The anti-inflammatory effect of a tocolytic drug is of a great value because it may relieve a silent but ongoing inflammation and prolong pregnancy. The therapeutic strategy for the prevention of preterm births that might have inflammatory origin should focus on agents which can inhibit early uterine contractions and also able to control inflammation and its consequences for the mother and infant. According to the present findings, the $\beta_{2}$-AR agonists have an enhanced uterus relaxant effect after an LPS challenge, and they also have anti-inflammatory properties. Detection of the underlying causes of preterm labor contractions is not an easy task, though interventions might be more specific and effective if the ongoing inflammatory process is diagnosed.

Acknowledgments This work was supported financially by National Council for Research and Technology (NKFP) Budapest (RET 08/2004). We thank Zsuzsanna Magyar, Zsuzsanna Tóth, and Adrienn Gál for their technical assistance in the experiments.

\section{References}

Berkman ND, Thorp JM Jr, Lohr KN, Carey TS, Hartmann KE, Gavin NI (2003) Tocolytic treatment for the management of preterm labor: a review of the evidence. Am J Obstet Gynecol 188:1648-1659

Bilski AJ, Halliday SE, Fitzgerald JD, Wale JL (1983) The pharmacology of a beta 2-selective adrenoceptor antagonist (ICI 118,551). J Cardiovasc Pharmacol 5:430-437

Bradford MM (1976) A rapid and sensitive method for the quantitation of microgram quantities of protein utilizing the principle of protein-dye binding. Anal Biochem 72:248-254

Challis JRG, Matthews SG, Gibb W, Lye SJ (2000) Endocrine and paracrine regulation of birth at term and preterm. Endocr Rev 21:514-550
Challis JR, Sloboda DM, Alfaidy N, Lye SJ, Gibb W, Patel FA (2002) Prostaglandins and mechanisms of preterm birth. Reproduction 124:1-17

Combe B (2001) Thalidomide: new indications? Joint Bone Spine 68:582-587

de Heus R, Mulder EJ, Derks JB, Visser GH (2008) Acute tocolysis for uterine activity reduction in term labor - a review. Obstet Gynecol Surv 63:383-388

Elovitz MA, Mrinalini C (2004) Animal models of preterm birth. Trends Endocrinol Metab 15:479-487

Farmer P, Pugin J (2000) beta-Adrenergic agonists exert their "antiinflammatory" effects in monocytic cells through the IkappaB/ NF-kappaB pathway. Am J Physiol Lung Cell Mol Physiol 279: L675-682

Garfield RE, Saade G, Buhimschi C, Buhimschi I, Shi L, Shi SQ, Chwalisz K (1998) Control and assessment of the uterus and cervix during pregnancy and labour. Hum Reprod Update 4:673-695

Gaspar R, Foldesi I, Havass J, Marki A, Falkay G (2001) Characterization of late-pregnant rat uterine contraction via the contractility ratio in vitro significance of alpha1-adrenoceptors. Life Sci 68:1119-1129

Gaspar R, Ducza E, Mihalyi A, Marki A, Kolarovszki-Sipiczki Z, Paldy E, Benyhe S, Borsodi A, Foldesi I, Falkay G (2005) Pregnancy-induced decrease in the relaxant effect of terbutaline in the late-pregnant rat myometrium: role of G-protein activation and progesterone. Reproduction 130:113-122

Gaspar R, Gal A, Galik M, Ducza E, Minorics R, KolarovszkiSipiczki Z, Klukovits A, Falkay G (2007) Different roles of alpha2-adrenoceptor subtypes in non-pregnant and late-pregnant uterine contractility in vitro in the rat. Neurochem Int 51:311-318

Giamarellos-Bourboulis EJ, Poulaki H, Kostomitsopoulos N, Dontas I, Perrea D, Karayannacos PE, Giamarellou H (2003) Effective immunomodulatory treatment of Escherichia coli experimental sepsis with thalidomide. Antimicrob Agents Chemother 47: 2445-2449

Gogarten W, Lindeman KS, Hirshman CA, Emala CW (2003) Tumor necrosis factor alpha stimulates adenylyl cyclase activity in human myometrial cells. Biol Reprod 68:751-757

Goldenberg RL, Hauth JC, Andrews WW (2000) Intrauterine infection and preterm delivery. N Engl J Med 342:1500-1507

Guo M, Pascual RM, Wang S, Fontana MF, Valancius CA, Panettieri RA, Tilley SL, Penn RB (2005) Cytokines regulate $\beta_{2}$-adrenergic receptor responsiveness in airway smooth muscle via multiple PKA- and EP2-receptor mediated mechanisms. Biochem 44: 13771-13782

Harrison C, Traynor JR (2003) The $\left[{ }^{35}\right.$ S]GTPgammaS binding assay: approaches and applications in pharmacology. Life Sci 74:489-508

Iams JD, Romero R, Culhane JF, Goldenberg RL (2008) Primary, secondary, and tertiary interventions to reduce the morbidity and mortality of preterm birth. Lancet. 371:164-175

Kam KY, Lamont RF (2008) Developments in the pharmacotherapeutic management of spontaneous preterm labor. Expert Opin Pharmacother 9:1153-1168

Kim YS, Kim JS, Jung HC, Song IS (2004) The effects of thalidomide on the stimulation of NF-kappaB activity and TNF-alpha production by lipopolysaccharide in a human colonic epithelial cell line. Mol Cells 17:210-216

Klukovits A, Gáspár R, Sántha P, Jancsó G, Falkay G (2004) Role of capsaicin-sensitive nerve fibers in uterine contractility in the rat. Biol Reprod 70:184-190

Lindström TM, Bennett PR (2005) The role of nuclear factor kappa B in human labor. Reproduction 130:569-581

Maris NA, de Vos AF, Dessing MC, Spek CA, Lutter R, Jansen HM, van der Zee JS, Bresser P, van der Poll T (2005) Antiinflammatory effects of salmeterol after inhalation of lipopolysaccharide by healthy volunteers. Am J Respir Crit Care Med 172:878-884 
Méhats C, Schmitz T, Oger S, Hervé R, Cabrol D, Leroy MJ (2007) PDE4 as a target in preterm labour. BMC Pregnancy Childbirth 7 (Suppl 1):S12

Osawa Y, Yim PD, Xu D, Panettieri RA, Emala CW (2007) Raf-1 kinase mediates adenylyl cyclase sensitization by TNF-alpha in human airway smooth muscle cells. Am J Physiol Lung Cell Mol Physiol 292:L1414-1421

Peltier MR (2003) Immunology of term and preterm labor. Reproductive Biology and Endocrinology 1:122-132

Romero R, Mazor M, Wu YK, Sirtori M, Oyarzun E, Mitchell MD, Hobbins JC (1988) Infection in the pathogenesis of preterm labor. Semin Perinatol 12:262-279

Sartori C, Fang X, McGraw DW, Koch P, Snider ME, Folkesson HG, Matthay MA (2002) Lung edema clearance: 20 years of progress. Selected contribution: long-term effects of $\beta_{2}$-adrenergic receptor stimulation on alveolar fluid clearance in mice. J Appl Physiol 93:1875-1880

Schmitz T, Souil E, Hervé R, Nicco C, Batteux F, Germain G, Cabrol D, Evain-Brion D, Leroy MJ, Méhats C (2007) PDE4 inhibition prevents preterm delivery induced by an intrauterine inflammation. J Immunol 178:1115-1121

Sim LJ, Selley DE, Childers SR (1995) In vitro autoradiography of receptor-activated $\mathrm{G}$ proteins in rat brain by agonist-stimulated guanylyl 5'-[gamma- $\left[{ }^{35} \mathrm{~S}\right]$ thio]-triphosphate binding. Proc Natl Acad Sci USA 92:7242-7246

Smith GN (2003) What are the realistic expectations of tocolytics? BJOG 20:103-106

Traynor JR, Nahorski SR (1995) Modulation by mu-opioid agonists of guanosine- $5^{\prime}-O-\left(3-\left[{ }^{35} \mathrm{~S}\right]\right.$ (thio)triphosphate binding to membranes from human neuroblastoma SH-SY5Y cells. Molecular Pharmacology 47:848-854

Watts DH, Krohn MA, Hillier SL, Eschenbach DA (1992) The association of occult amniotic fluid infection with gestational age and neonatal outcome among women in preterm labor. Obstet Gynecol 79:351-357

Withworth M, Quenby S (2008) Prophylactic oral betamimetics for preventing preterm labour in singleton pregnancies. Cochrane Database Syst Rev 23:CD006395

Wray S, Kupittayanant S, Shmygol A, Smith RD, Burdyga T (2001) The physiological basis of uterine contractility: a short review. Exp Physiol 86:239-246

Yoon BH, Kim YA, Romero R, Kim JC, Park KH, Kim MH, Park JS (1999) Association of oligohydramnios in women with preterm premature rupture of membranes with an inflammatory response in fetal, amniotic, and maternal compartments. Am J Obstet Gynecol 181:784-788 